\title{
Impact of Training on Improving Proper Handwashing Practices among Elementary School Students
}

\author{
Theruna Huthamaputiran, ${ }^{1}$ Sunarjati Sudigdoadi, ${ }^{2}$ Andriana Purnama ${ }^{3}$ \\ ${ }^{1}$ Faculty of Medicine Universitas Padjadjaran, ${ }^{2}$ Department of Microbiology and Parasitology \\ Faculty of Medicine Universitas Padjadjaran, ${ }^{3}$ Department of Surgery Faculty of Medicine \\ Universitas Padjadjaran/Dr. Hasan Sadikin General Hospital, Bandung
}

\begin{abstract}
Background: Hand washing is among the most effective ways to prevent diseases. In Indonesia, only a quarter of the entire population practice proper handwashing techniques. Of these, children are the most vulnerable group for contracting diseases. Nevertheless, they also are crucial agent for behavior transformation as they are keen and open to new ideas. Therefore, this study was conducted to determine if training would have an improvement on a proper hand washing practices among elementary school students.

Methods:An observational descriptive study design using random sampling was conducted from September to November 2013 in Jatinangor Subdistrict, West Java, Indonesia using primary data of one hundred elementary school students from four elementary schools. Questionnaires were given after informed consent. A demonstration on hand washing techniques and education on proper hand washing practices was then given. Two weeks later, the same questionnaire was given to measure the influence of the training. The collected data were presented using frequency tabulation.

Results: Before the training on proper hand washing practices was conducted, only $86.9 \%$ students were practicing it properly. After the training was given, $90.7 \%$ of the students were doing it properly. For the hand washing technique, only $66.8 \%$ of students knew the correct steps before the intervention was given and $78.7 \%$ students did them correctly after the intervention.
\end{abstract}

Conclusions:The training shows an overall improvement on the students' hand washing practices.

Keywords: Elementary school students, hand washing, Jatinangor, technique, training

\section{Introduction}

Our hands are the part of our body that serve as the port of entry for microbes. It is essential to practice proper hand washing as it is the initial defense of various hand borne transmissible diseases. ${ }^{1}$ Worldwide diarrheal diseases were significant contributors of child mortality under 5 years of age. In Indonesia ${ }^{2}$, diarrhea is responsible for $25-31 \%$ deaths of children. Only $23.2 \%$ of the entire populations have correct hand washing habits which is usually only done before having meals and after defecating. ${ }^{2}$ Various studies indicate that hand washing with soap is among the most effective and inexpensive ways to prevent diarrheal diseases. ${ }^{3,4}$ Current evidence shows the usage of soap decreases the incidence of diarrhea by
$53 \%{ }^{5}$ Shockingly, even developing countries display low incidence of hand washing with soap ranging only from 0 to $20 \%{ }^{6}$

The main organism causing diarrhea among children is Escherichia coli. ${ }^{7}$ It can be transmitted from infected feces to people through water and food, person-to-person contact, or direct contact. ${ }^{8}$ Intervention on hand hygiene and proper hand washing technique shows tendency to improve hand washing habits and practices. ${ }^{9}$ Therefore, inspiring school students to develop proper hand washing behavior will lead them to maintain this behavior into adulthood, and this will contribute in fulfilling the fourth Millennium Development Goal which is to reduce child mortality. ${ }^{1}$

The aim of this study was to evaluate the implementation of hand washing among

Correspondence: Theruna Huthamaputiran, Faculty of Medicine, Universitas Padjadjaran, Jalan Raya BandungSumedang Km.21, Jatinangor, Sumedang, Indonesia, Phone: +6283816260482 Email: halcyondays_24@yahoo.com 
elementary school students after training.

\section{Methods}

A descriptive study was conducted from September-November 2013 in four elementary schools (Cileles, Cikeruh I, Sayang, and Cipacing I) in Jatinangor, West Java, Indonesia. This study was approved by the Health Research Ethics Committee, Faculty of Medicine, Universitas Padjadjaran.

A total of 124 sixth grade students were selected randomly from a total of 1,438 students. Selected students were given informed consent form to be approved by their parents or guardians. Selection criteria were based on the students' willingness to participate in this study. Students who were absent on the day the data were taken and those who did not complete the questionnaire appropriately were excluded from the study.

A total of 100 students fulfilled the criteria with a response rate of $80.6 \%$. They were given their first questionnaire the next day. It consisted of three sections, the first was about their identity (name, gender and age) and the second section was about their hand washing practice consisting of ten questions. In the third section, the students were required to match randomized pictures to their appropriate techniques of hand washing. After collecting these initial questionnaires, the proper hand washing steps were demonstrated and they were taught the proper hand washing practices. After two weeks, the same questionnaire was given to these students.

The collected data were then classified into pre-intervention and post-intervention data based on questionnaire 1 and 2 respectively. The frequencies of correct and wrong answers were then calculated to see if the training had any influence on them.

\section{Results}

Most of the questions had a positive response except on the questions regarding the usage of towels or tissues to dry hands, washing hands before meals, and the hand washing practices after cleaning or disposing trash (Table 1).

In terms of hand washing practices, there were increases of correctness in most of the steps, except the step number 2 (Table 2).

\section{Discussion}

This study discovered that before the training of a proper hand washing practices were performed, lesser students used to practice proper hand washing practices, but after the training, the number of students washing their hands after certain scenario increased.

Table 1 Hand washing Practice before and after Training

\begin{tabular}{|c|c|c|c|c|}
\hline \multirow{2}{*}{ Question } & \multicolumn{2}{|c|}{ Before } & \multicolumn{2}{|c|}{ After } \\
\hline & Yes & No & Yes & No \\
\hline Do you always wash your hands with tap water? & 94 & 6 & 100 & 0 \\
\hline Do you always use soap to wash your hands? & 87 & 13 & 97 & 3 \\
\hline $\begin{array}{l}\text { Do you always use tissues or towels to dry your } \\
\text { hand? }\end{array}$ & 91 & 9 & 91 & 9 \\
\hline $\begin{array}{l}\text { Do you always wash your hands after using the } \\
\text { toilet? }\end{array}$ & 94 & 6 & 96 & 4 \\
\hline Do you always wash your hands before meals? & 93 & 7 & 93 & 7 \\
\hline Do you always wash your hands after meals? & 98 & 2 & 100 & 0 \\
\hline $\begin{array}{l}\text { Do you always wash your hands after sneezing or } \\
\text { coughing? }\end{array}$ & 57 & 43 & 66 & 34 \\
\hline $\begin{array}{l}\text { Do you always wash your hands after cleaning or } \\
\text { disposing trash? }\end{array}$ & 91 & 9 & 89 & 11 \\
\hline Do you always wash your hands when you fall down? & 75 & 25 & 84 & 16 \\
\hline $\begin{array}{l}\text { Do you always wash your hands after touching or } \\
\text { playing with animals? }\end{array}$ & 89 & 11 & 91 & 9 \\
\hline
\end{tabular}


Table 2 Proper Hand Washing Technique

\begin{tabular}{ccccc}
\hline \multirow{2}{*}{ Hand washing steps } & \multicolumn{2}{c}{ Before } & \multicolumn{2}{c}{ After } \\
\cline { 2 - 5 } & Correct & Wrong & Correct & Wrong \\
\hline 1 & 78 & 21 & 94 & 6 \\
2 & 100 & 0 & 97 & 3 \\
3 & 45 & 55 & 78 & 22 \\
4 & 49 & 51 & 74 & 26 \\
5 & 40 & 60 & 57 & 43 \\
6 & 38 & 62 & 61 & 39 \\
7 & 79 & 21 & 89 & 11 \\
8 & 68 & 32 & 57 & 43 \\
9 & 79 & 21 & 86 & 14 \\
10 & 92 & 8 & 94 & 6 \\
\hline
\end{tabular}

However, there were still a few questions that show no improvement or even became worse after the intervention.

It showed that question 2 had the most difference while question 3 and 5 had no changes. Also note that question 8 had negative difference after the intervention was given. When asked further about question 3 , in which the respondents were asked if they use hand towels or tissues to dry their hands after washing their hands, they replied that they do not always have access to hand towels or tissues after washing their hands, so they will wipe their hands on their clothes or not wipe at all. This will later on develop into a habit, and further into a social norm.

Question 5 which asked the respondents if they wash their hands before meals, showed that they were reluctant and avoided to answer the questions asked to them. Then it can be seen that there is lack of influence and supportive role of their parents or families to exercise the proper habits and etiquettes of hand washing. A similar study conducted by Peananukulbut ${ }^{10}$ in 2012 on the elementary school students of Selat Sub district showed that students not washing hands before meals are the third highest. Question 8 exhibited a negative outcome. It is because there is a reduction of 2 students washing their hands after taking out the thrash.

Number of students answering correctly increased after the intervention was given compared to previous number of students. Question 3 showed the highest improvement. However, question 2 showed a negative improvement. The increase in step 3 suggested that the intervention had made them aware of why it is important to lather their hands before proceeding to other steps. In addition, another reason why students skip or do not practice a few steps correctly was also found while demonstrating the proper hand washing techniques to the students, which was because they felt hand washing habits should not take a lot of time. When observed, they tended to not wash their hands with soap and just proceed to rub their palms and the back of their hands like step 4.

Despite that, step 2 showed a decrease of 2 students failing to match the correct steps with their appropriate description. Step 10 received the least increase. This can be considered normal because previously, even without the intervention, 92 students already managed to get the correct answer compared to 94 after intervention. This small increase of students using the disposable towels or tissues to wipe their hands after washing hands can be attributed to the lecture given by the lecturer as to why drying hands is important after washing hands. This fact is bolstered by the fact that most visited schools do not have a tissue box or a towel dispenser in their toilets. It was then inferred that the students may be simply hindered by the lack of facilities that the schools offer.

Limitations of this study included the dishonesty of the student in answering the questionnaires which result in a few invalid results. This can be attributed to the lack of supervision when conducting this study. Therefore, the study on the subsequent schools was repeated with supervision of 
their teachers. Further limitations included the lack of given concentration during demonstration and education. Some of the students were not paying attention during the demonstration, thus, when they were asked to fill in the questionnaire after the intervention was given, a few of them tended to copy their classmate's answers and not answering their questionnaires honestly.

Furthermore, it is also worth stating that the results of this questionnaire should be higher than that of what is actually practiced by the students in reality. Most of the students claimed that they can properly execute the hand washing steps, but when asked to demonstrate personally, they tended to make mistakes. Other factors included subject recall bias. It was also noted that when the students were asked why they do not washing their hands after throwing rubbish, they tended to forget to wash their hands. This is also coherent with the results outlines in this previous study. ${ }^{10}$

Based on the results of the study, most students showed improvement after the intervention was given. Therefore, it can be concluded that the education on proper hand washing practice and training on proper hand washing techniques had a positive impact on the students. As a recommendation for future studies, the study should be conducted in small groups of 5 students instead of 25 for each school where the students will be asked to perform hand washing steps individually to know if they really understand the proper techniques. Teachers should aid the researcher and be more attentive in controlling the classroom to maintain discipline to avoid dishonest answers and students copying each other.

More awareness posters, stickers, and materials to improve knowledgeand awareness of hand washing should be available in schools to increase awareness among their students. Teachers and the school curriculum should integrate personal hygiene as a core value to instill these traits in their students and create generation of young students that are aware of the importance of hand washing.

From this study, it can be concluded that there is a modest positive impact on the students' hand washing practices and techniques after the intervention was given.

\section{References}

1. World Alliance for Patient Safety. WHOguidelines on hand hygiene in health care: advanced draft. Geneva: WHO Press.2006.

2. UNICEF INDONESIA. Ringkasan Kajian: air bersih, sanitasi \& kebersihan. Jakarta: UNICEF; 2012 [cited 2013 November 12]. Available from: www.unicef.or.id

3. Fewtrell L, Kaufmann RB, Kay D, Enanoria W, Haller L, Colford JM. Water, sanitation, and hygiene interventions to reduce diarrhoea in less developed countries: a systematic review and meta-analysis. Lancet Infect Dis. 2005;5(1):42-52.

4. Curtis V, Cairncross S. Effect of washing hands with soap on diarrhoea risk in the community: a systematic review. Lancet Infect Dis. 2003;3(5):275-81.

5. Luby SP, Agboatwalla M, Feikin DR, Painter J, Billhimer W, Altaf A, et al. Effect of handwashing on child health: a randomised controlled trial. Lancet. 2005;366(9481):225-33.

6. Scott B, Curtis V, Rabie T, GarbrahAidoo N. Health in our hands, but not in our heads: understanding hygiene motivation in Ghana. Health Policy Plann. 2007;22(4):225-33.

7. Greene LE, Freeman MC, Akoko D, Saboori S, Moe C, Rheingans R. Impact of a schoolbased hygiene promotion and sanitation intervention on pupil hand contamination in Western Kenya: a cluster randomized trial.Am J Trop Med Hyg. 2012;87(3):38593

8. Ejemot-Nwadiaro RI, EhimiJE, Meremikwu MM, Critchley JA. Hand washing for preventing diarrhoea. Cochrane Database of Syst Rev. 2008;1:CD004265

9. Apriany D. Perbedaan perilaku mencuci tangan sebelum dan sesudah diberikan pendidikan kesehatan pada anak usia 4-5 tahun. Jurnal Keperawatan Soedirman. 2012;7(2):60-6.

10. Setyautami T, Sermsri S, Chompikul J. Proper hand washing practices among elementary school students in Selat subdistrict, Indonesia. J Pub Health Dev. 2012;10(2):3-20. 